\title{
DEVELOPMENT OF AMERICAN BOLLWORM, HELICOVERPA ARMIGERA (HÜBNER) (LEPIDOPTERA: NOCTUIDAE) IN RELATION TO HEAT UNIT REQUIREMENT
}

\author{
AMER, A.E.A., A.A.A. EL-SAYED AND M.A. NADA \\ Plant Protection Research Institute, ARC, Dokki Giza \\ (Manuscript received 10 March 2009)

\begin{abstract}
Laboratory Experiment were carried out to study the effect of different temperature's degrees, $\left(15,20,25,27\right.$ and $\left.30^{\circ} \mathrm{C}\right)$ on the developmental stages of the American bollworm (ABW) Helicoverpa armigera (Hübner) reared on artificial diet. As temperature increased from 15 to $30^{\circ} \mathrm{C}$ the life span decreased. The lower thermal threshold for the development of $\mathrm{ABW}$ eggs is $13.01{ }^{\circ} \mathrm{C}$, for larvae is $11.98{ }^{\circ} \mathrm{C}$, for pupal stage is $9.79{ }^{\circ} \mathrm{C}$ and for pre-ovipostion period is $12.83{ }^{\circ} \mathrm{C}$. The thermal constant for the development of eggs is 36.69 day degree (DD's), for larvae is 245.17 DD's, for the pupal stage is 181.64 DD's and 34.99 DD's for the pre-ovipostion period. The lower thermal threshold for generation of $A B W$ is $11.54^{\circ} \mathrm{C}$ and the thermal constant is 494.39 DD's. Obtained results are essential information for predicting the field population of $A B W$.
\end{abstract}

\section{INTRODUCTION}

Helicoverpa armigera (Hübner) (Lepidoptera: Noctuidae) is an important pest of many crops in many parts of the world (Sharma, 2001). The thermal requirements (degree-days) for the development are often used for estimating developmental times because temperature has a major effect in determining the rate at which insects develop (Zaslavski, 1988). The information of thermal constants and lower development thresholds provide essential information to determine the development rate of a particular species of arthropod (Honek, 1996, Jarosik et al. 2002). The lower thermal threshold for total development (from egg to adult emergence) of ABW reared on corn seeds is $11.5^{\circ} \mathrm{C}$ and the thermal constant is 625.0 DD's (Bartekova and Praslicka, 2006). Applied biologists have been interested for a long time in predicting the date of emergence of the spring brood of insects. It is well established that the rates of development during different stages of the life-cycle of many insects depend on the temperatures to which they are exposed (Cunningham et al. 1981).

The aim of this study is to determine the lower development threshold and thermal constants for development of ABW. 


\section{MATERIALS AND METHODS}

The present work was carried out in Bollworms research Department, Plant Protection Research Institute, Sharkia Branch to evaluate the effect of temperature on the development of ABW stages. The experiment was performed at five constant temperatures, $15,20,25,27$ and $30 \pm 1^{\circ} \mathrm{C}$.

\section{Insect rearing}

The stage of ABW larvae were collected from cotton fields in Daquahlia Governorate during June and July of 2007 cotton growing season and brought to the laboratory. It was fed separately on un-matured cotton seed in glass tubes $(3 \times 7.5$ $\mathrm{cm}$ ) covered with absorbent cotton wool. The food was daily renewed until pupation. Pupae were transferred to clean glass tubes and incubated until moth emergence. When adults emerged, moths were sexed and caged to egg laying. Moths were provided with $10 \%$ honey solution on a cotton swab. The eggs were separated daily and placed in glass jars. Obtained eggs were used in experiment.

\section{Development of immature stages:}

Eggs laid on the same day ( $<24$ old) were placed in glass jar and incubated under five constant temperatures $\left(15,20,25,27\right.$ and $\left.30^{\circ} \mathrm{C}\right)$ and $65 \pm 5 \%$ R.H. Three replicates of 100 eggs/each were used for each tested temperature's degree. The number of eggs hatched was recorded daily and egg's incubation period was calculated. The hatched Larvae in each temperature's treatment were used for the developmental studies at the respective temperatures.

Newly hatched larvae were transferred individually to glass tubes $(3 \times 10 \mathrm{~cm})$ containing about 5-6 g artificial diet (Rashad and Ammar, 1985) each tube were plugged tightly with absorbent cotton and placed in an incubator at constant of 15 , $20,25,27$ and $30^{\circ} \mathrm{C}$ and $65 \pm 5 \%$ R.H. Four replicates of 25 larvae/ each were used for each tested temperature. Larvae were examined daily until pupation to record larval duration. Pupae were transferred to clean glass tubes and examined daily until moth emergence to record pupal duration. When adults emerged, moths were sexed and caged to egg laying. Moths were provided with $10 \%$ honey solution. The cages were inspected daily until moth death. The pre-ovipostion, oviposition and postovipostion periods and longevity of adult females and males were calculated.

\section{- Statistical analysis}

The effect of temperature's degrees $\left(20,25,27\right.$ and $\left.30^{\circ} \mathrm{C}\right)$ on developmental time of ABW was determined by analysis variance (ANOVA). The relationship between temperature and mean developmental rate of each stage and generation under tested temperature was determined using liner regression. Except rate of ABW's development at $15 \mathrm{C}$ not included in our analysis. For each temperature, developmental rate (DR) were calculated as reciprocals of development time (DT) of 
individual ABW's stages $(D R=1 / D T)$. The relations between developmental rate $(D R)$ and temperature $(T)$ was determined using liner regression equation: $D R=a+b T$, whereas: $a, b$ parameters of the liner regression. The lower developmental threshold $(L D T)$, i.e. the temperatures when development ceases, was determined: $L D T=-a / b$. On the other hand, degree days (DD's) for completion development of each stage was calculated according to Arnold (1959): DD's $=\mathrm{DT} *\left(\mathrm{~T}-\mathrm{t}_{0}\right)$ where, $\mathrm{DT}-$ development time of a given stage, $T$ - temperature in degree centigrade and $t_{0 \text { - }}$ lower developmental threshold.

\section{RESULTS AND DISCUSSION}

Temperature dependence of ABW development is summarized in Table (1). The incubation period of $\mathrm{ABW}$ was 13.7 days on $15^{\circ} \mathrm{C}$, with increasing temperature, the developmental times of the egg stage were shortened, i.e. on $20^{\circ} \mathrm{C}$ to 5.0 days, on $25^{\circ} \mathrm{C}$ to 3.2 days, on $27{ }^{\circ} \mathrm{C}$ to 2.7 days and on $30^{\circ} \mathrm{C}$ to 2.1 days. The statistical analysis of the obtained data showed that there are significant differences between the average of incubation period at $20^{\circ} \mathrm{C}$ and all other regimes. There are no significant differences between the values on 25,27 and $30^{\circ} \mathrm{C}$ degrees. These results are in agree with those obtained by Jallow and Matsumura (2001) who reported that $2.5-14.1$ days of egg development, depending on temperature $\left(32.5-13.5^{\circ} \mathrm{C}\right)$.

Table (1) show the rate of development of the different life history stages in relation to temperature is expressed by the linear regression equation. According to the regression line, equation the lower developmental threshold of ABW's eggs was $13.01{ }^{\circ} \mathrm{C}$, and the thermal constant for their development was 36.69 DD's. Kay (1981) reported that the lower developmental threshold of ABW's egg was $11.7^{\circ} \mathrm{C}$. Bartekova and Praslicka (2006) found that the lower developmental threshold of ABW's egg's was $14.8^{\circ} \mathrm{C}$ when fed on corn seeds.

The development of larvae On $15^{\circ} \mathrm{C}$, required 44.0 days. With increasing temperature, the developmental times of the larval stage were shortened, i.e. on 20 ${ }^{\circ} \mathrm{C}$ to 31.1 days, on $25^{\circ} \mathrm{C}$ to 18.4 days, on $27^{\circ} \mathrm{C}$ to 16.3 day and on $30^{\circ} \mathrm{C}$ to 13.7 days. There were significant differences in the duration of larval stage on the different temperatures (Table 1). Other authors recorded similar values for larval stage. Jallow

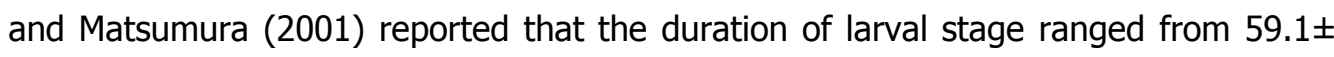
4.69 days at $13.3^{\circ} \mathrm{C}$ to $10.9 \pm 0.14$ days at $32.5^{\circ} \mathrm{C}$. Bartekova and Praslicka (2006) reported 18.27-39.30 days for larval development, depending on temperature. According to the regression line equation, the lower developmental threshold of ABW's larvae was $11.98^{\circ} \mathrm{C}$, and the thermal constant for their development was 245.17 DD's (Table 1). A developmental threshold of $11.3^{\circ} \mathrm{C}$ and 215.1 day-degrees were estimated for ABW larvae by Jallow and Matsumura (2001). 
Table 1. Effect of different temperatures on biological aspect of Helicoverpa armigera.

\begin{tabular}{|c|c|c|c|c|c|c|c|c|c|c|c|c|c|c|c|c|}
\hline \multirow{2}{*}{\multicolumn{2}{|c|}{$\begin{array}{c}\text { Temp. } \\
\left({ }^{\circ} \mathrm{C}\right)\end{array}$}} & \multicolumn{3}{|c|}{ Egg stage } & \multicolumn{3}{|c|}{ Larval stage } & \multicolumn{3}{|c|}{ Pupal stage } & \multicolumn{3}{|c|}{ Pre-ovipostion } & \multicolumn{3}{|c|}{ Generation } \\
\hline & & DT & $\mathrm{DR}$ & $\mathrm{DD}$ & DT & $\mathrm{DR}$ & $\mathrm{DD}$ & DT & DR & $\mathrm{DD}$ & DT & $\mathrm{DR}$ & $\mathrm{DD}$ & DT & DR & DD \\
\hline \multicolumn{2}{|c|}{15} & 13.7 & - & - & 44.0 & - & - & 251.0 & - & - & - & - & - & - & - & - \\
\hline \multicolumn{2}{|c|}{20} & $5.0 \mathrm{a}$ & 0.20 & 34.95 & $31.1 \mathrm{a}$ & 0.03 & 249.42 & $17.9 a$ & 0.06 & 182.76 & $4.7 a$ & 0.21 & 33.70 & $58.7 a$ & & 496.60 \\
\hline \multicolumn{2}{|c|}{25} & $3.2 b$ & 0.31 & 38.37 & $18.4 b$ & 0.05 & 239.57 & $11.8 \mathrm{~b}$ & 0.08 & 179.48 & $3.0 \mathrm{~b}$ & 0.33 & 36.51 & $36.4 b$ & & 489.94 \\
\hline \multicolumn{2}{|c|}{27} & $2.7 \mathrm{bc}$ & 0.37 & 37.77 & $16.3 c$ & 0.06 & 244.83 & $10.6 \mathrm{bc}$ & 0.09 & 182.43 & $2.5 b$ & 0.40 & 35.43 & $32.1 \mathrm{c}$ & & 496.27 \\
\hline \multicolumn{2}{|c|}{30} & $2.1 \mathrm{c}$ & 0.48 & 35.68 & $13.7 d$ & 0.07 & 246.87 & $9.0 \mathrm{c}$ & 0.11 & 181.89 & $2.0 \mathrm{~b}$ & 0.50 & 34.34 & $26.8 d$ & & 494.73 \\
\hline \multicolumn{2}{|c|}{ Mean } & & & 36.69 & & & 245.17 & & & 181.64 & & & 34.99 & & & 494.39 \\
\hline \multicolumn{2}{|c|}{ LSD 0.05} & 1.188 & & & 1.883 & & & 1.833 & & & 1.930 & & & 3.766 & & \\
\hline \multirow{2}{*}{ 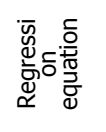 } & a & \multicolumn{3}{|c|}{-0.355411} & \multicolumn{3}{|c|}{-0.04894} & \multicolumn{3}{|c|}{-0.05391} & \multicolumn{3}{|c|}{-0.36649} & \multicolumn{3}{|c|}{-0.02334} \\
\hline & $b$ & \multicolumn{3}{|c|}{0.027211} & \multicolumn{3}{|c|}{0.004084} & \multicolumn{3}{|c|}{0.005507} & \multicolumn{3}{|c|}{0.028549} & \multicolumn{3}{|c|}{0.002023} \\
\hline \multicolumn{2}{|c|}{ LDT } & \multicolumn{3}{|c|}{13.01} & \multicolumn{3}{|c|}{11.98} & \multicolumn{3}{|c|}{9.79} & \multicolumn{3}{|c|}{12.83} & \multicolumn{3}{|c|}{11.54} \\
\hline
\end{tabular}

$\mathrm{DT}=$ Development time in days,

$\mathrm{DD}=$ degree days

$\mathrm{a}=$ intercept
$\mathrm{DR}=$ development rate

LDT $=$ Lower developmental threshold

$\mathrm{b}=$ slope 
Pupa entered diapause at $15{ }^{\circ} \mathrm{C}$, while pupae were classified as having entered diapause if adult emergence was delayed beyond 251.0 days at $15{ }^{\circ} \mathrm{C}$ (Table 1). The duration of non-diapaused pupa decreased as temperature increased from 17.9 days on $20^{\circ} \mathrm{C}$ to 11.8 days on $25^{\circ} \mathrm{C}, \quad 10.6$ days on $27^{\circ} \mathrm{C}$ and 9.0 days on $30{ }^{\circ} \mathrm{C}$. Statistical analysis of the obtained data showed that there are significant differences between the average of pupal stage duration on $20^{\circ} \mathrm{C}$ and all other regimes. There are no significant differences between the values on 25,27 and $30^{\circ} \mathrm{C}$. The previously mentioned results are similar to those obtained by Mironidis and Soultani (2008) who reported that the duration of pupal stage of ABW ranged from 9.07 day on $30.0^{\circ} \mathrm{C}$ to 20.8 days on $20^{\circ} \mathrm{C}$. According to the regression line equation the lower developmental threshold of $H$. armigera pupa was $9.79{ }^{\circ} \mathrm{C}$, and the thermal constant for their development was 181.64 DD's (Table 1).

The mean time required for maturation of the ovaries and starting egg laying, decreased as the temperature increased from 4.7 days on $20^{\circ} \mathrm{C}$ to 2.00 days at $30^{\circ} \mathrm{C}$. Statistical analysis of the obtained data showed that there are significant differences between the average of pre-ovipostion period on $20^{\circ} \mathrm{C}$ and all other regimes. There are no significant differences between the values at each of 25,27 and $30^{\circ} \mathrm{C}$. The lower development threshold of pre-ovipostion period was $12.83^{\circ} \mathrm{C}$, and the thermal constant for their development was 34.99 day-degrees (Table 1).

Generally, the mean duration of generation (from eggs to pre-ovipostion) for ABW were 58.7 days on $20^{\circ} \mathrm{C}, 36.4$ day on $25^{\circ} \mathrm{C}, 32.1$ days on $27^{\circ} \mathrm{C}$ and 26.8 days on $30{ }^{\circ} \mathrm{C}$. There were significant differences in the generation time at the different temperatures (Table 1). According to the regression line equation the lower developmental threshold of ABW generations was $11.54{ }^{\circ} \mathrm{C}$, and the thermal constant for their development was 494.39 DD's (Table 1). Bartekova and Praslicka (2006) reported that the lower thermal threshold for the total development (from egg to adult emergency) of $\mathrm{ABW}$ is $11.5^{\circ} \mathrm{C}$ and the mean thermal constant is $625.0 \mathrm{DD}$ 's. Mironidis and Soultani (2008) reported that the lower thermal threshold for total development (from egg to adult emergency) of ABW reared on artificial diet is $9.57^{\circ} \mathrm{C}$ and the thermal constant is 476.19 day-degrees. Differences between the results obtained in this study and those of other studies could be attributed to the different origin of ABW, i.e. strain and geographical region, as well as the different experimental condition, i.e. rearing techniques and food. Population from different geographical regions may differ in various reproductive and life history aspects (Papadopulos et al. 2002).

On the other hand, the oviposition and post-oviposition periods of $A B W$ were also affected by temperature. The longest periods ( 8.7 and 3.4 days) were achieved 
on $20^{\circ} \mathrm{C}$ and the lowest 4.25 and 1.5 days on $30^{\circ} \mathrm{C}$, respectively. Statistical analysis of the obtained data showed that there are significant differences between the oviposition period or post-ovipostion periods at $20^{\circ} \mathrm{C}$ and all other regimes. There are non significant differences between the values at 25,27 and $30^{\circ} \mathrm{C}$ (Table 2).

In addition, the average life span of adult female and male of ABW decreased as the temperature increased from 16.18 and 15.00 days on $20^{\circ} \mathrm{C}$ to 7.75 and 7.30 days on $30^{\circ} \mathrm{C}$, respectively. Statistical analysis of the obtained data showed that there are significant differences between the adult female longevity on $20^{\circ} \mathrm{C}$ and all other regimes. There are no significant differences between values on 25 and $27{ }^{\circ} \mathrm{C}$, for female longevity and 27 and $30^{\circ} \mathrm{C}$ for male longevity (Table 2).

Table 2. Effect of different temperatures on female and male longevity of Helicoverpa armigera

\begin{tabular}{|c|c|c|c|c|}
\hline \multirow{2}{*}{ Temperature $\left({ }^{\circ} \mathrm{C}\right)$} & $\begin{array}{c}\text { Oviposition } \\
\text { period }\end{array}$ & \multirow{2}{*}{ Post- oviposition } & \multicolumn{2}{|c|}{ Longevity } \\
\cline { 4 - 5 } & $8.7 \mathrm{a}$ & $3.4 \mathrm{a}$ & $15.0 \mathrm{a}$ & $16.8 \mathrm{a}$ \\
\hline 20 & $6.2 \mathrm{~b}$ & $2.2 \mathrm{~b}$ & $11.1 \mathrm{~b}$ & $11.4 \mathrm{~b}$ \\
\hline 25 & $5.7 \mathrm{bc}$ & $1.7 \mathrm{bc}$ & $9.5 \mathrm{c}$ & $9.9 \mathrm{~b}$ \\
\hline 27 & $4.25 \mathrm{c}$ & $1.5 \mathrm{c}$ & $7.3 \mathrm{c}$ & $7.75 \mathrm{c}$ \\
\hline 30 & 1.883 & 0.449 & 1.883 & 1.883 \\
\hline LSD 0.05 & & & &
\end{tabular}

Results obtained from these studies may provide important information for predicting the field population of $\mathrm{ABW}$ or for predicting the timing of a barrier chemical treatment against ABW larvae in field crops.

\section{REFERENCES}

1. Arnold, C.Y. 1959. The determination and significance of the base temperature in a linear heat unit system. In Proc. Am. Soc. Hortic. Sci., 74:430-445.

2. Bartekova, A. and J. Praslicka. 2006. The effect of ambient temperature on the development of cotton bollworm (Helicoverpa armigera Hubner). Plant Protect. Sci., 42: 135-138.

3. Cunningham, R. B., T. Lewist and A. G. L. Wilson. 1981. Biothermal development: a model for predicting the distribution of emergence times of diapausing Helicoverpa armigera. App. Statist. 30(2): 132-140. 
4. Honek, A. 1996. The relationship between thermal constants for insect development: a verification. Acta Societaris Zoologicae Bohemicae, 60: 115-152.

5. Jallow, M. F. A. and M. Matsumura. 2001. Influence of temperature on the rate of development of Helicoverpa armigera (Hubner) (Lepidoptera: Noctuidae). Appl. Entomol. Zool., 36(4):427-430.

6. Jarosik, V., A. Honek and A. F. G. Dixon. 2002. Developmental rate isomorphy in insects and mites. The American Naturalist, 160:497-510.

7. Kay, I. R. 1981. The effect of constant temperatures on the development time of eggs of Heliothis armigera (Hübner) (Lepidoptera: Noctuidae) . J. Aust. Entomol. Soc., 20:155-156.

8. Mironidis, G. K. and S. Soultani. 2008. Development, survivorship, and reproduction of Helicoverpa armigera (Lepidoptera: Noctuidae) under constant and altermating temperatures. Environ. Entomol. 37(1):16-28.

9. Papadopoulos, N. T., B. I. Katsogianos And J. R. Carey. 2002. Demographic parameters of the Mediteranedn fruit fly (Diptera tephrididae) reared in apples, Ann. Entomol. Soc. Am , 95: 561-569.

10. Rashad- Amira, M. and Ammar. 1985. Mass rearing of spiny bollworm, Earias insulana (Boisd.) on semi artificial diet. Bull. Soc. Entomol., Egypt, 65:239-244.

11. Sharma, H. C. 2001. Cotton bollworm legume pod borer Helicoverpa armigera (Hubner) (Noctuidae Lepidoptera) biology and management. Crop Protection Compendion. International Crops Research Institute for the Semi-Arid Tropics.

12. Zaslavski, V. A. 1988. Insects development (Photo periodic and temperature control). Spinger-Verlag, Berlin. 187 pp. 


\section{تظور دودة اللوز الأمريكية وعلاقتها بالوحدات الحرارية}

\section{عادل السيد على عامر ، علي أحمد السيد ، محمد أحمد ندا}

$$
\text { معهُ بحوث وقاية النباتات - مركز البحوث الزراعية - الدقي - الجيزة }
$$

أجريت دراسات معملية بمعهد بحوث وقاية النباتات فرع الثرقية لدراسة تأثثر درجات الحرارة

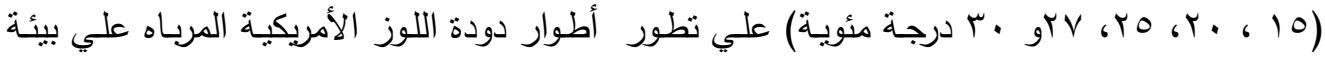

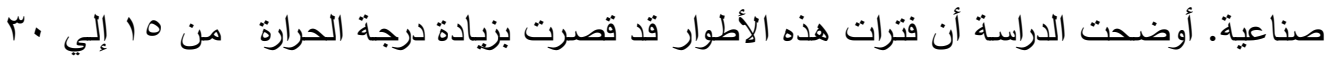

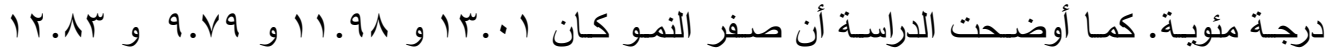
درجة مئويـة لطور البيضـة و اليرقة و العذراء وما قبل وضـع البيض علي التوالي. وكانت الوحدات

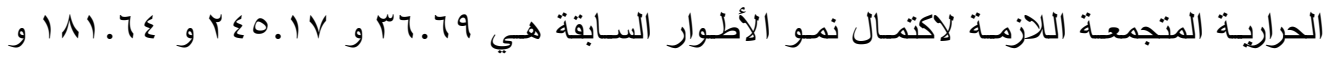

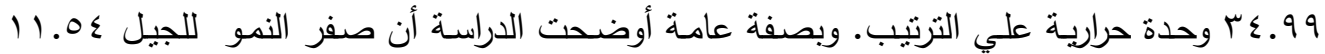

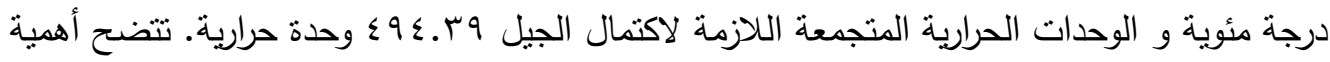
النتائج المتحصل عليها في إمكانية التتبؤ بتعداد دودة اللوز الأمريكية تحت الظروف الحقلية. 